\title{
Epistemic Democracy and Minority Rights
}

\author{
Kathleen M. Sullivan $\dagger$
}

Frank Michelman frames the dilemma of constitutional democracy as a variation on a dilemma posed by all democracy. The dilemma is this: Democracy consists of self-government. But there are winners and losers in particular democratic contests. How can the losers be understood as self-governing, rather than as subordinated to the will of the majority? There are two possible answers. One is substantive: the collectivity may be understood as self-governing so long as it acts consistently with an externally stipulated definition of democracy. The other answer is procedural: each participant, including a loser in short-run politics, may be understood as self-governing so long as he assented (either through actual agreement, or through the agreement implicit in his participation in the debate or failure to exit the jurisdiction) to the long-rnn procedures under which he lost.

But either answer, suggests Michelman, only moves the problem one step back. In a constitutional democracy, specification of the higher-order constitutional regine under which day-to-day politics takes place must itself be consistent with self-government. The relevant question is not only whether we govern ourselves in our politics, but also whether we govern ourselves in our constitutionalism.

At the threshold, Michelman mles out any historical solution to the question. We are not, in his view, constitutionally self-governing simply because our predecessors virtually represented us in agreeing upon a fundamental charter of structures and rights. Even putting aside the question of whether a sinall cadre of white male gentry truly represented all of "we the people," the Constitution they framed and ratified and its subsequent amendments are deliberately general and open-ended. Thus, the constitutional order consists not of a static text, but of the necessarily dynamic interpretation of that text in the context of new controversies. It is in that ongoing interpretive process, not the finite instant of the

Copyright $\odot 1998$ California Law Review, Inc.

$\dagger$ Stanley Morrison Professor of Law, Stanford University. 
founding, Michelinan argues, that constitutional democracy must be consistent with self-government. ${ }^{1}$

No formal procedures of ratification or ainendinent furnish a de1nocratic pedigree for this ongoing process of constitutional interpretation. Worse yet, its most authoritative pronouncenents are inade by unaccountable judges such as Michelinan's protagonist, Justice Brennan. When Brennan struck down a flag-burning law, ${ }^{2}$ a libel verdict won by a public official, ${ }^{3}$ a denial of uneinployinent benefits to a person whose religious observance cost her a job, ${ }^{4}$ or an exclusion of undocumented children from public schools, ${ }^{5}$ to take a few examples froin his extraordinary tenure on the Court, how could such outcomes be consistent with our constitutional self-governinent? Obviously such decisions defy the short-run inajorities who enacted or enforced the invalidated policies. The issue becomes whether we are self-governing with respect to the higher-order constitutional principles-freedom of speech, free exercise of religion, and equal protection of the law-in whose name Brennan reached such results.

Michelinan considers two possible accounts of how such rulings might be consistent with democratic self-government, and finds each of thein wanting. ${ }^{6}$ On the substantive account that Michelman attributes to Ronald Dworkin, the issue is not who inakes these decisions, but whether their content is consistent with a proper understanding of deinocracy. Laws that suppress dissent, protect rulers from criticism, discourage the exercise of conscience, or treat a group of persons as a subordinate caste, for example, might be found inconsistent with democracy even if passed by inajority vote. Invalidation of such laws on constitutional grounds is counter-majoritarian, but nonetheless democratic. In this view, constitutional rights serve as metademocratic correctives to the flaws that tend to infect day-to-day democratic politics.

But fatally lacking in this substantive approach, says Michelman, is any mechanism whereby the governed may choose to impose the relevant higher-order concept of democracy upon themselves, rather than have it stipulated or imposed by outside authorities such as Justice Brennan. Worse still, he asserts, no such mechanism could possibly exist. If democracy is an idea with determinate content, then a definition of that content logically must precede the operation of any democratic procedures to determine what it should be-how else would we know

1. Frank I. Michelman, Brennan and Democracy, 86 CALIF. L. Rev. 399, 402 (1998).

2. See United States v. Eichman, 496 U.S. 310 (1990); Texas v. Johnson, 491 U.S. 397 (1989).

3. See New York Times Co. v. Sullivan, 376 U.S. 254 (1964).

4. See Sherbert v. Verner, 374 U.S. 398 (1963).

5. See Plyler v. Doe, 457 U.S. 202 (1982).

6. For Michelman's treatment of the substantive account, see Michelman, supra note 1, at 410-20. For his treatment of the procedural account, see id. at 404-10. 
that the procedures are democratic? And there is no guarantee that a group acting democratically would choose. "democracy" as independently defined; the group might just as well choose oligarchy or some other system (out of false consciousness or simply persuasive argument in the course of robust debate). Thus, a substantive account of how the constitutional order promotes self-government, Michelman asserts, cannot be given by self-government itself. ${ }^{7}$

Equally unpersuasive to Michelman is Robert Post's effort at a purely procedural account of democratic constitutionalism. In Post's view, democratic self-government exists if everyone has unfettered access to robust public dialogue and if legislative outcomes are provisional, always subject to revision upon further public debate. Democratic constitutionalism, it follows, exists if similarly endless debate is possible about our fundamental, higher-order law (even if there are higher structural barriers to constitutional amendment than to legislative repeal). If such preconditions obtain, there is no independent content to democratic self-government or democratic constitutionalism; each consists simply of whatever the participants in the dialogue decide. No matter how fractional or ultimately futile our individual contribution to the policy or application of the fundamental law that emanates from the contest among competing opinions, the opportunity to make that contribution can amount to self-government by enabling us to identify with the outcomes that emerge.

Michelman, however, argues that no account of self-government can be "purely" procedural because in the end it must rest upon some substantive content-for example, the substantive desirability of ceaseless communication without preclusive government censorship. Post furnishes no mechanism for the people to choose that substantive end for themselves. Nor could he, presumably; by Michelman's logic, dialogue is no more certain to produce an argument for dialogue than democratic procedures are to define correctly the content of democracy. ${ }^{8}$

To settle the dialectic between these antithetical substantive and procedural accounts of constitutional self-government, Michelman proposes a novel synthesis: epistemic democratic constitutionalism. ${ }^{9}$ It shall be up to Justice Brennan, not democratic participants themselves, to decide what the fundamental laws say about the permissibility of short-run political outcomes. But Brennan's constitutional interpretation shall be legitimate only insofar as it is informed by the irreducibly diverse perspectives of contemporary democratic participants who expose him to

7. See Part V of Michelman's lecture, Michelman, supra note 1, at 419-20.

8. See Part III.C of Michelman's lecture, id. at 407-10.

9. See Part VI of Michelman's lecture, id. at 420-24. 
the "full blast of [their] sundry opinions." Michelman's synthesis is substantive to the extent that it considers judges institutionally suited to imterpret the fundamental law in relation to an external definition of democratic self-government. His synthesis is procedural to the extent that judges' interpretations depend on democratic participation-on "critical interaction" among the people, and between the people and judges."1

Michelman's distinctive twist is to redefine the relevant procedural participation as epistemic rather than political. In his view, it is sufficient that participation in constitutional self-government take the form of intellectual enlightenment of Justice Brennan, rather than any actual control (however slight) we might have over his decisions. One may govern oneself by serving as an informant to the process, even if one does not serve as a moral agent.

It is difficult, however, to see how this proposal successfully reconciles constitutionalism with self-government. Even an oligarch or benevolent despot might believe it helpful or prudent to canvass broadly the people's opinions and interests in the course of reaching a decision; there is nothing necessarily democratic in this process. Being informed by the views of the people is not the same as being made accountable to them. By Michelman's own argument, the people are not uniquely, or even especially competent to prescribe the substantive content of constitutional democracy. No matter how exquisitely attuned Justice Brennan may be to the variety of opinions expressed in an ideal epistemic exchange, he will still have to decide for himself which of them best conform to the principles of constitutional democracy-at least if those principles are to be defined, as Michelman (unlike Post) requires, independently of the process of epistemic exchange itself.

Moreover, even if robust public dialogue about the appropriate content of the fundamental law could resolve the self-government problem conceptually, constitutional adjudication--Justice Brennan's domain-is a strange place to look for resolution as a practical matter. Constitutional adjudication is strictly limited in scope by case or controversy requirements, the ban on advisory opinions, and prudential customs such as the avoidance of political questions. Further, the Supreme Court narrowly restricts the grant of discretionary review and limits such review to closely circumscribed questions presented. Briefing is performed principally by the parties, whose particular relation to the constitutional question at issue is fortuitous. Within the existing conventions of constitutional adjudication, the closest approximation of Michelman's proposal for broad epistemic inputs is the amicus curiae brief,

10. See id. at 423 .

11. See id. 
which may indeed express perspectives and opinions apart from those of the parties. But amicus briefs are heard only by parties' consent or the Court's permission, and the Court is not obliged to read them; nor is there reason to expect that they will be broadly representative of all of society's sundry views. The Court might hear the informal public opinion expressed in editorial pages and in street demonstrations, but its institutional practices preclude any self-conscious advertence to such sources.

In light of these constraints, it is difficult to see why the path of Michelman's epistemic democratic constitutionalism leads to Justice Brennan. Epistemic pluralism about constitutional meaning seems more apt to manifest itself in the drafting of legislation or formal constitutional anendments, or in informal legislative reprisals against judicial constitutional pronouncements. Legislatures or constitutional conventions are accountable to the people whose views they consider; in these forums, politics precedes epistemology. Michelman, it seems, should favor constitutionally populist institutions that would shrink the amount of fundanental-law interpretation done by courts in relation to that done by the people. Surprisingly, however, he proposes instead to assimilate the Court's constitutionalism to these kinds of politics, broadly understood. In so doing, he inverts previous arguments, such as those associated with Alexander Bickel, that the Court's distinctive competence to discern "procedure-independent standards of rightness" arises from its insulation from politics, not its immersion in it.

Even if the robust display of epistemic pluralism were institutionally feasible before the Court, it is far from clear that Justice Brennanthe empirical Justice Brennan-sought to listen to all frequencies at the same volume, or value as epistemically equal the perspective of all participants. Rather, what was distinctive about so many of his opinions was that he took the minority perspective. When invalidating the handiwork of political majorities, he spoke for the little guy, for the civil rights worker, for the labor organizer, for the man on the way to the gas chamber, for the woman who wished not to be pregnant, for the child born out of wedlock or to illegal alien parents, for the diffuse and anonymous minority of the poor. In short, he spoke for persons on the short end of the government stick.

The most straightforward account of such constitutional interpretations is one that combines a substantive view of democracy with a representation-reinforcing institutional vision of the Court: Democratic selfgovernment rightly understood means self-government for everyone. Those systematically unlikely to be able to realize their own interests through government because they are outnumbered, despised, or socially subordinated, must have rights against certam disadvantageous 
outcomes they are powerless to prevent. Some decisions on matters of faith or private conscience must be immunized by judges from majoritarian political resolution so that individuals may be self-governing on such matters one by one.

Michelman resists any such substantive account standing alone; he finds it a necessary but not sufficient condition for democratic constitutionalism. The reason seems to be that he is uncertain where such a substantive account could possibly come from. He correctly denies that it can come in any fully explanatory sense from the vague and openended text of the Constitution, because any particular application of that text, and of the broader metaprinciples underlying it, involves a complicated interpretive process. And he implicitly denies that the source can be transcendental: the rights of minorities or dissidents do not exist in or emanate from nature; they are not metaphysical essences standing outside political processes as trumps, but are themselves to be derived from democratic processes as appropriate himits on the reach of democratic outcomes. He also implicitly denies that the source can be a hypothetical bargain: the rights of minorities or dissidents cannot be merely what we think we would have provided if we did not know in advance whether we would end up as minority or dissident. Instead, to avoid the pitfalls of imterpretive authoritarianisin or foundationalism, he would require some source for minority rights in actual contemporary public discourse among the governed.

But public discourse is the last place we are likely to find any consensus that minority rights constrain the majority. The very legislation or policy being challenged is the best evidence that the majority public opinion rejects such rights, at least in the relevant instance. Justice Brennan cannot simultaneously behave as an epistemic egalitarian and overturn the majority's will $\mathrm{m}$ the name of minority rights. Rather, he must be epistemically selective - that is, place highly restrictive conditions on what he recognizes as informative political debate. Deciding when the perspectives of losers in the political process should have been taken into account in public dialogue requires criteria. But such criteria will turn out to look suspiciously like rights emanating froin "above" or "outside" politics-just what Michelman's epistemic procedural condition was meant to avoid. A ruling for the minority is inore an exercise of epistemic equity than epistemic democracy.

There remains, though, one possible source for minority rights that lies somewhere between metaphysics and textual authority on the one hand and contemporary public discourse on the other. That source is constitutional tradition-the cultural identity of the people strnctured over time through a set of customs and precedents. Arguably, Justice Brennan's most distinctive contribution to constitutional jurisprudence 
was to read such traditions at a broad enough level of generality to link them to new minority claims of right. The Michael $H$. opinion that Michelman highlights was exemplary; Brennan there rooted the child visitation right he would have granted to an unmarried father not simply in an abstract privacy norm but in the liberty interests that "society traditionally has thought inportant."12 That reading was arguably not just moral but culturally democratic-an effort to link the right claimed to some set of attitudes or principles fashioned (at least implicitly) by the people. Brennan's opinions spoke not in the broad and timeless absolutes of a Justice Black or Douglas, but in the fine-grained and meticulous craft of a constitutional common lawyer-with a capacious view of the relevant body of precedential materials, to be sure. Perhaps the procedural ground Michelman seeks for the substantive norms of constitutional democracy, so difficult to locate in contemporary public opinion, is best found, if one insists on looking for it, in this realm of ongoing constitutional culture. That culture allowed Justice Brennan, in foiling contemporary majorities, at least to argue that "it isn't just me and my moral commitments speaking; it is us."

12. Michael H. v. Gerald D., 491 U.S. 110, 140 (1989) (Brennan, J., dissenting) (emphasis added). 
CALIFORNIA LAW REVIEW 